\title{
Long-Term Sustainability Approach in Road Traffic Noise Wall Design
}

\author{
Maja Ahac, Saša Ahac *(D) and Stjepan Lakušić * \\ Department for Transportation Engineering, Faculty of Civil Engineering, University of Zagreb, \\ 10000 Zagreb, Croatia; maja.ahac@grad.unizg.hr \\ * Correspondence: sasa.ahac@grad.unizg.hr (S.A.); stjepan.lakusic@grad.unizg.hr (S.L.)
}

Citation: Ahac, M.; Ahac, S.; Lakušić, S. Long-Term Sustainability Approach in Road Traffic Noise Wall Design. Sustainability 2021, 13, 536 . https://doi.org/10.3390/su13020536

Received: 20 November 2020

Accepted: 6 January 2021

Published: 8 January 2021

Publisher's Note: MDPI stays neutral with regard to jurisdictional clai$\mathrm{ms}$ in published maps and institutional affiliations.

Copyright: (C) 2021 by the authors. Licensee MDPI, Basel, Switzerland. This article is an open access article distributed under the terms and conditions of the Creative Commons Attribution (CC BY) license (https:// creativecommons.org/licenses/by/ $4.0 /)$.

\begin{abstract}
Despite the long-term experience in the application of noise walls, the uncertainty in wall panel service life efficiency is almost equal between panels built from established and new materials, which are-because of the desire to increase the sustainability of noise walls-developing at an everfaster pace. The presented meta-analysis of data collected during a systematic review of concrete, metal, and wood panels' acoustic and non-acoustic characteristics, long term performance, and cradleto-gate sustainability aims to reduce this uncertainty and support the process of noise wall design and management by shifting the emphasis in decision making from construction costs to the long-term sustainability of the road traffic noise mitigation project. The multi-criterial analysis showed that when choosing a panel, preference should be given to those using lightweight concrete materials. A further comprehensive cradle-to-grave assessment of lightweight concrete panels with expanded clay and recycled tire rubber aggregates, which was performed to fill a knowledge gap observed in the literature and identify opportunities for the improvement of lightweight concrete sustainability, showed that the main environmental impacts of these panels are due to their production processes and that the way to reduce such impacts is to use panels made with aggregates from secondary raw materials.
\end{abstract}

Keywords: systematic review; meta-analysis; wall panel; material; multi-criterial analysis; lightweight aggregate; cradle-to-grave

\section{Introduction}

According to the data provided by the European Environment Agency (EEA), noise pollution is a major environmental health problem in Europe [1] that is causing issues like sleep disorders leading to period of unwanted awakening [2], learning impairments [3-6], hypertension ischemic heart disease [7-9], and especially annoyance [10,11]. Road traffic is the dominant noise source in urban and suburban areas. According to the Environmental Noise Directive (END) 2002/49/EC, EU Member States are required to determine exposure to environmental noise from major transport and industry sources by means of strategic noise maps [12]. Strategic noise maps are the basis for the preparation, adoption, and publication of action plans for the prevention and reduction of harmful noise exposure, and the specific measures included in the action plans are decided at the Member State level [12,13].

In the last few years, noise action plans have aimed at raising awareness of noise as an environmental problem and promoting the use of more environmentally friendly modes of transport (electric vehicles, vehicles with quieter engines, and low-noise tires [14]). Moreover, new mitigation systems for road traffic (the main source of noise) were proposed, and several projects have been devoted to producing extended real-time noise measurements to obtain a realistic picture of the noise distribution over urban areas [15]. Still, road traffic noise remains a significant environmental problem: Around 100 million people in EU Member States are exposed to road traffic noise levels above $55 \mathrm{~dB}(\mathrm{~A})$ Lden, while 32 million are exposed to very high noise levels above $65 \mathrm{~dB}(\mathrm{~A})$ Lden [1]. Lden is 
defined as "a descriptor of noise level based on energy equivalent noise level (Leq) over a whole day with a penalty of $10 \mathrm{~dB}(\mathrm{~A})$ for night-time noise (23.00-7.00) and an additional penalty of $5 \mathrm{~dB}(\mathrm{~A})$ for evening noise (19.00-23.00)" [16].

Road traffic noise is mainly produced by road-tire interactions [17], and the most important parameters affecting noise emission are the tire model [18], pavement age [19,20], and pavement texture [21-23] and mixture [24,25]. Because of the abovementioned factors, a common solution for road traffic noise abatement used both in urban and suburban environments is targeting noise sources through road traffic management, e.g., by replacing road surfaces and introducing low-noise road surfaces, improving the traffic flow, and lowering speed limits. In urban agglomerations, this measure is followed by measures related to land use and urban planning. The second most commonly used measure applied to major roads ("a regional, national or international road, designated by the Member State, which has more than three million vehicle passages a year" [12]) located outside residential areas is changing the noise propagation paths through the construction of noise barriers between the noise source and the receiver [14]. The term "noise barrier" can be used to encompass every type of structure used to reduce noise, including earth mounds, noise walls, and their combinations [26]. New types of noise barriers-sonic crystal noise barriers-were also developed recently [27-29]. All these structures differ in terms of their construction elements. An earth mound features a berm at the top and sloping sides, noise walls are constructed from horizontally stacked panels [26], while sonic crystal noise barriers are non-homogeneous structures created from the arrangement of scatterers in a periodic configuration with square, rectangular, or triangular patterns [27].

The application of road traffic noise barriers began more than 50 years ago in both the USA and Europe [30,31]. The noise wall exploitation behavior, repair, and/or replacement frequency of aged or deteriorated wall panels became an important issue in the last decade. However, despite the long-term experience in the application of noise walls (and research on the sustainability of noise barriers as well as other noise abatement measures [32-36]), when deciding on the panel material to be used in the design phase, designers still encounter numerous uncertainties associated with the exploitation behavior of noise walls constructed with panels made from different materials [37], including their stability, durability, and resistance to fire, impacts, and atmospheric influences. The main question is how the imminent degradation of panels will affect the efficiency of the wall structure, its life-cycle costs, and its long-term sustainability in specific locations and conditions. There is a wide range of materials available for the construction of panels (wood, woodcrete, concrete, glass/glasscrete, stone/brick, aluminum/steel, acrylic, etc.), and all panels can be systematized into four basic types: concrete, metal, wood, and transparent. The uncertainty in panel service life quality is almost equal between the panels built from established materials and the panels built from new materials, which are now developing at an ever-faster pace due to the desire to increase the sustainability of noise walls [37].

The choice of panel material is influenced by several factors, including the noise wall dimensions, location and local environmental conditions, aesthetic requirements (including local architectural considerations, public perception, and acceptance of the structure), and price [38]. According to [39], different approaches are taken when choosing the panel material within various countries in the EU. In northern EU countries, the landscape approach is the most prominent, in central EU countries, the technical approach (functionality and durability of the wall) is employed first, followed by the architectural approach, and, in southern EU countries, a cost-wise approach (lowest price criterion) dominates when choosing a panel material [39].

The abovementioned distribution of the approaches among EU Member States is not surprising since new southern Member States have yet to fully develop and implement their road traffic noise pollution abatement measures, including the construction of noise barriers. For instance, strategic noise mapping conducted on the Croatian highway network showed that more than $520 \mathrm{~km}^{2}$ of sensitive areas are exposed to road traffic noise levels above $55 \mathrm{~dB}(\mathrm{~A})$ Lden [40] along $1300 \mathrm{~km}$ of the network [41]. Developed action plans 
consider addressing the issue of high levels of road traffic noise primarily by constructing noise walls [42]. The key issue here is that noise walls can use as many resources and have as much of an impact on the built environment as other large structures, even though they are still broadly considered road equipment. The price, i.e., the expenditure of public funds, is usually a major deciding factor for the scale of a typical noise wall project. The average cost of approximately $120 € / \mathrm{m}^{2}$ for the cheapest option-a wall with timber panels-installed on both sides of the carriageway with a total length of $4 \mathrm{~km}$ and an average height of $4 \mathrm{~m}$ amounts to a total resource cost of nearly 2 million $€$ [43]. Furthermore, the choice of panel material plays an important role in the overall sustainability of noise walls. The sustainability of a noise wall is broadly defined as the optimal consideration of technical, environmental, economic, and social factors during the design and construction, maintenance and repair, and removal/demolition stages of noise wall projects [43]. Therefore, in the design phase, to control the costs of the construction, maintenance, and removal of noise walls, it is necessary to obtain all relevant information on the characteristics of the panels based on which the satisfactory and rational selection of their materials can be made [37].

The aim of the research presented in this paper was to reduce uncertainty in the selection of panel materials during the noise wall design phase and to support the process of road traffic noise protection management in Southern European countries by shifting the emphasis in decision making from the panel's initial price (price of acquisition and installation) to the long-term sustainability and safety of the entire road traffic noise protection project. Section 2 provides a systematic overview of the concepts and EU regulations related to noise reducing devices and the required panel characteristics. By reviewing the publicly available literature and databases, the characteristics of concrete, metal, and wood panels were identified and systematized as follows: the share of panels used on infrastructure, common panel composition, acoustic performance, mechanical resistance and stability, safety requirements, procedures and installation costs, service life expectancy and durability, lifecycle costs, cradle-to-gate sustainability, and recyclability. The observed trends in the choice of panel materials during the last 50 years facilitated a more detailed review of lightweight concrete panels made with expanded clay, plant biomass, and recycled tire rubber aggregates. Section 3 presents the results of a meta-analysis on concrete, metal, and wood panels conducted by comparing the reported panels' acoustic and non-acoustic characteristics and economic and environmental sustainability features. The scores used in the multi-criteria analysis and the results of the performed evaluation are then presented. To fill a knowledge gap observed in the literature, we also provide the input data and results of the cradle-to-grave approach in a comparative lifecycle assessment of lightweight concrete panels with expanded clay and rubber granules. Section 4 discusses the results and interprets them from the perspectives of previous studies and the working hypotheses. Future research directions are also highlighted. Section 5 concludes the paper.

\section{Background}

Despite the availability of various types of construction materials, the European market is dominated by three noise wall panel types: concrete, metal, and wood [44]. Over $80 \%$ of EU member states use one of these three major types of materials or their combinations [45]. The same situation is noted in the USA, where, according to the Federal Highway Administration (FHWA) Inventory [46], walls constructed with a single material (either concrete, metal, or wood) make up $84 \%$ of all noise walls. Concrete panels consist of two layers: load-bearing panels, up to $20 \mathrm{~cm}$ thick, a reinforced concrete layer, and an absorbing layer made of lightweight porous concrete (with 3-5 mm aggregate grains of expanded clay, wood fibers, and rubber granules), usually up to $15 \mathrm{~cm}$ thick. Metal panels are made of (galvanized) steel, stainless steel, or aluminum and consist of two lacquered plates, 0.5 or $1 \mathrm{~mm}$ thick, between which stone wool $(50,80$, or $100 \mathrm{~mm}$-thick) is installed. Wooden panels are made of solid or laminated wood or plywood. Panels with a willow front and stone-wool interior are also considered to be wooden in some publications. Due to 
the above, the present review of the literature and standards is limited to wall panels made primarily of concrete, metal, and wood.

\subsection{Characteristics of Concrete, Metal, and Wood Panels}

When designing road traffic noise walls, all EU Member States must respect the CEN/CENELEC Internal Regulations European Standards for Road Traffic Noise Reducing Devices Acting on Airborne Sound Propagation written by CEN/TC 226/WG 6 [47]. This package can be subdivided into four main sub-packages: acoustic characteristics, non-acoustic characteristics, long-term performance, and sustainability of road traffic noise reducing devices $[38,44,48]$. The following is an overview of the characteristics required by these packages, based on which a further comparison of the efficiency and sustainability of noise walls with respect to the materials of their panels is given.

\subsubsection{Acoustic Characteristics}

To ensure the acoustic efficiency of the noise wall, the position and height of the wall must prevent line-of-sight contact between the noise source and the receiver, and its panels must be sufficiently thick and made of acoustically suitable material (in density and porosity). The required acoustic performance of road traffic noise reducing devices is given in a set of EN 1793 standards [47]. The basic parameters that describe a wall's acoustic properties are sound absorption/reflection $\left(\mathrm{DL}_{\alpha}\right)$ and sound insulation $\left(\mathrm{DL}_{\mathrm{R}}\right)$. The efficiency of walls in reducing noise is expressed by the insertion loss (IL) parameter.

The sound absorption ability of wall panels is crucial for the effectiveness of noise walls. The greater the ability of the panel to absorb the sound, the lower the reflection of the sound wave from the wall towards the objects on the opposite side of the road and back towards the vehicles (the noise source). Panels whose $\mathrm{DL}_{\alpha}$ is greater than $10 \mathrm{~dB}$ are considered to have good absorption properties [38]. Non-absorbing or reflecting noise walls will allow the sound to travel over the noise wall after repeated reflections between the wall and the vehicles. Due to this sound wave behavior, the use of panels with few or no absorption properties (such as transparent panels) can cause the sound level to increase in the vicinity of the receiver behind the noise wall. An increase in noise levels at the receiver due to such reflections can be as high as $+3 \mathrm{~dB}(\mathrm{~A})$ [38].

The sound insulation property is defined by the loss of sound energy, which occurs when a sound wave passes directly through a wall. The sound insulation provided by a barrier is dependent upon many factors, such as surface density, stiffness, loss factors, and the angle of incidence of the sound. The most significant of these is the surface density of the barrier [26]. A panel is considered to have sufficient insulating properties if its surface density is $20 \mathrm{~kg} / \mathrm{m}^{2}$ or higher [49].

Insertion loss is defined as the reduction of the noise level in $\mathrm{dB}(\mathrm{A})$ at a given location due to the placement of a noise reduction device in the sound path between the sound source and that location. A properly designed noise wall should attain an IL approaching $10 \mathrm{~dB}(\mathrm{~A})$, which is equivalent to a perceived halving of loudness for the first row of homes directly behind the wall [50]. Field investigations performed in [51] showed that the correlation between wall insertion loss and material type is the greatest among the observed location and walls characteristics, such as a wall's height and its distance from the roadway, air temperature and humidity, total traffic volume, and average speed.

\subsubsection{Non-Acoustic Characteristics}

The required non-acoustic characteristics of road traffic noise reducing devices are given in a set of EN 1794 standards [47]. The general required technical characteristics of noise walls include mechanical resistance and stability and safety characteristics.

Safety characteristics address fire resistance, light reflection, the risk of falling debris, and emergency escapes. The required fire resistance of a noise wall is reflected in the limitations set for the use of both flammable and non-flammable materials, which could develop toxic gases or wind-borne embers if affected by open flames from a forest fire 
or traffic accidents. Fire resistance is a major safety issue for wood panels. In the case of the smooth metal panels, a major safety issue is the reflection of light, e.g., glare that can disturb road users. This negative phenomenon is more pronounced when using lighter colored panels and occurs both during the day (in the morning and evening when the sun rays are at a small angle) and at night (due to the use of lights, which is especially pronounced if the panel surface is wet). The use of panels with rougher surfaces and deeper relief designs, like concrete panels, can reduce or eliminate this problem.

The mechanical performance and stability requirements for noise walls are ensured by the proper design and installation of the wall elements (panels, columns, and foundations). A constant load in the form of the panel's own weight, which mainly depends on the panel's material, is especially important when designing walls on viaducts, bridges, retaining, and abutment structures. If it is not possible to make alterations in such structures that would ensure their higher load-bearing capacity, lightweight panels are usually chosen. In addition to a constant load, the greatest load that the wall structure can resist is defined by the wind. The wind load depends on the geographical location of the structure and may also depend on the ratio of the altitude of the location and the surrounding topography. If the wall is located very close to the road, additional dynamic loads must be taken into account, such as aerodynamic forces due to the passage of heavy vehicles, forces due to the possible impact of vehicles and airborne debris on the structure and horizontal pressure from snow accumulated along the lower parts of the wall structure after clearing snow from the road.

Concrete panels have many advantages, including high durability, stability, and resistance, as well as numerous fastening and panel design options. They can also be molded into a wide range of different shapes so that they can easily be incorporated into any landscape. The significant weight of concrete panels, although favorable in terms of the resistance and stability of the final structure (especially in locations with high wind loads), can be a problem. This weight can increase the transport costs over long distances and often require special installation techniques and equipment. Their weight also makes such panels unsuitable for installation on viaducts and bridges. The standard panel width of $4 \mathrm{~m}$ (column spacing) requires lower costs for the construction of foundations and columns. The manipulation of heavy concrete panels requires the use of cranes that, if mounting is done from the carriageway, obstruct traffic during installation.

Metal panels, due to their lower weight, are the usual choice for installation on bridges and viaducts, on existing retaining walls with a limited load-bearing capacity, and when there is a need to increase the height of existing noise walls. The costs of delivering these panels to the construction site are small in comparison to the costs related to concrete walls. When installing aluminum panels, care must be taken to prevent direct contact of the aluminum with other metals (primarily steel) since aluminum reacts similarly to zinc in galvanizing processes, i.e., it acts as a "sacrificial" element that will shortly disintegrate. Anti-corrosion coatings on metal panels are mandatory in cases of high exposure to salt and moisture. Moreover, since all metal panels are conductive, their installation is not desirable near electrical lines if the proper grounding of all metal components cannot be ensured. Metal panels are easily installed using cranes. The possible closure of road traffic during the construction of such walls is rather short in duration, but for the execution of fastenings, it is necessary to provide scaffolding whose installation can require a significant amount of space, work, and time. The usual length of metal panels of $3 \mathrm{~m}$ requires higher costs for foundation and column construction compared to concrete panels.

Wood panels are often the first choice for landscape architects; due to their low weight, their transportation costs to the construction site are small. Wood panels are inserted between posts and then fastened together with nails or screws, which are preferably made of non-corrosive metal (stainless steel or aluminum). The main advantage of this method of fastening is the possibility of the quick and easy assembly and disassembly of the noise wall, which is why traffic closures during construction are short. These panels are easily installed 
with the use of cranes, but, as with metal panels, it is necessary to provide scaffolding for the execution of the fastenings.

\subsubsection{Long-Term Performance}

Standardized procedures for the assessment of the long-term acoustic and non-acoustic performance of road traffic noise reducing devices were published in 2015 in a set of EN 14389 standards. In general, the panel material and wall construction design should provide long term durability against the effects of weathering and varying climate change, a long service life with minimal maintenance (or no maintenance), the efficient removability of the wall for repair or at the end-of-life, and consistent acoustic performance throughout the panel's service life.

Durability and resistance against the possible impacts of climate change affect the acoustic and non-acoustic performance of noise walls and determine how often they require major repairs or replacement. The selection of an appropriate panel material depends primarily on the obligations of the designer to follow the prescribed technical requirements to ensure the long service life of the structure in local conditions. In doing so, it is necessary to consider the resistance of the material to possible freezing and thawing phenomena, the influence of road water, the impact of UV radiation, and the behavior of the material at local temperature extremes.

The service life of a noise wall can be defined as the time over which the wall continues to optimally fulfil its task. This is the carefree period [37] featuring no major changes in the acoustic and physical properties or appearance of the panels-i.e., the time from wall construction to the time that the wall needs to be replaced. This time mostly depends on the panel material: The expected service life of concrete panels is 40 years, that of metal steel is 20 to 25 years, that of metal aluminum is 30 years, and that of wood is 20 or more years, depending on the protection type $[44,52]$.

Maintenance of a noise wall is vital to ensure its optimum performance during its service life and to ensure that any necessary repairs resulting from natural weathering or physical damage are made. While most EU member states have some form of a general maintenance programme for maintaining existing roads, less than $20 \%$ of them have specific protocols for the maintenance of noise walls [45]. The following exploitation behaviors and maintenance issues during the noise wall service life were reported in [44,51,53-55].

Concrete panels are very resistant to damage caused by vehicle and debris impacts, pressure from snow removal deposits, and other phenomena during maintenance. The rough surfaces of these panels do not attract graffiti artists because they require the use of a larger amount of paint, which is why vandalism is usually not a problem. Because they withstand extreme temperature changes, UV radiation, moisture, ice, and salt very well, maintenance related to the structural and aesthetic integrity of such a wall structure is rarely carried out. In the case of an absorbent layer made with wood fibers, damage to this layer in the lower parts of the structure ( $1 \mathrm{~m}$ from the ground surface) due to moisture is possible. The absorbent layer made with an expanded clay aggregate can also peel off due to impact and is not resistant to freezing.

Metal panels gradually rust, which is a result of the large amounts of moisture and salt in the air. If the panels are not coated with anti-corrosion paint or galvanized, the rust from the panels will very quickly spread to other elements of the wall. Even at low panel stresses caused by normal temperature changes, warping can occur if there are no reinforcing rods inside the panel. In addition, the low resistance and small thickness of the metal plates make these panels very susceptible to damage due to vandalism, debris, or vehicles; regular road maintenance; and snow clearing. Due to their smooth surfaces, they are a frequent target of graffiti artists.

Wood panels are not structurally strong and shatter easily in the event of a vehicle impact. Moreover, they are not dimensionally stable; they warp and shrink over time due to atmospheric influences (sun, moisture) or insect attacks. This causes cracks to appear along joints, especially if the wood was not dried enough before the panel was produced, 
which reduces wall effectiveness of the panel's noise protection. The warping problem during exploitation is proportional to the thickness of the panels. Although impregnated wood is used in their production, wood panels require periodic coatings, primarily to ensure the protection of the panels from moisture and insects but also due to the fading of their original color. Repairs or replacements of damaged parts are intrusive unless they are carried out using elements that were procured at the same time as the wall was installed and were exposed to the same weather conditions over that time. There is a high possibility that metal fastenings will react chemically adversely over time when in contact with certain types of protective coatings. Wood impregnation or coating is a major problem in the case of fire due to the emissions of harmful gases into the environment.

\subsubsection{Cradle-to-Gate Sustainability}

The Construction Product Regulation (305/2011/EU-CPR) [56], in force from the second half of 2013, promotes a new approach in product qualification based on a declaration of performance against seven essential requirements. The sustainability of construction products has been specifically addressed as the new seventh basic requirement. Sustainability as a topic entered the EU noise reduction device standards framework in 2014, but no standards have yet been published [47].

The sustainability of noise reduction devices during their whole lifecycle (in the planning and design, manufacturing and construction, maintenance and repair, removal, and demolition phases) was addressed in the QUIESST project [43], where guidelines were presented for the first viable method to assess a noise reduction device's sustainability. However, due to the lack of available data on the use, maintenance, and removal of noise walls related to the panel material, only the effect of panel production, i.e., cradle-to-gate sustainability, in quantities corresponding to a wall length of $1 \mathrm{~km}$ and a height of $2 \mathrm{~m}$ were analyzed in this project [44]. The panel production carbon footprint, water footprint, primary energy use (defined by natural resources before they are subject to change by and for human needs), and energy consumption due to panel transport (assuming transport by rail over $1 \mathrm{~km}$ ) were analyzed. The analysis considered the calculated average acoustic damping, thickness, weight, and surface density of the panel with respect to the material, with additional considerations of material recyclability and assumed durability. The following conclusions were made in the QUIESST project about the cradle-to-gate sustainability of panels and their impact on the environment during production.

The production of concrete panels has the largest carbon footprint but, at the same time, the smallest water footprint. The production of wood willow panels has the smallest carbon footprint but, at the same time, the largest water footprint. The production of metal panels also requires a significant amount of water. Primary energy consumption is the lowest for wood panels. The negative effect of transport in the form of energy consumption is the most pronounced for concrete panels due to the maximum total weight of materials needed for their production. It was concluded that, from a sustainability point of view, the most unfavorable process is the production of wood panels due to the very small amount of recyclable materials that can be used in the production process and the large amounts of water needed for the growth and processing of this natural resource.

All materials considered in the analysis can either be recycled or use recycled components, but special disposal procedures need to be provided for aluminum, steel, and wood panels because they contain minerals or stone wool, a non-recyclable material. The problem of recyclability is most pronounced in wood panels. Removing and disposing of wood panels can be dangerous for the environment because of the various protective coatings that are used in the production and maintenance of such panels. Wood panels also burn like any other wood, and the smoke and ash that are released into the environment due to the combustion of treated wood (arsenic, benzene, chromium, creosote, and pentachlorophenol) are considered toxic. At the end of their lifecycle, due to their exposure to weather conditions, wood panels are usually not of sufficient quality for reuse or recycling. Moreover, the issue of deforestation has been raised recently. 


\subsection{Panel Material Trends}

Noise walls have been established as noise management solutions on major roads in EU member states and in the USA for many years, and their positive and negative characteristics recorded during that time reflect the trends in their application. Since no systematized historical data on the application of a certain type of panel on road infrastructure at the EU level was found, in this research, the historical data (from 1973 to 2017) from the publicly available FHWA inventory of noise walls were used [46]. The results of the data analysis regarding the year the walls were originally constructed and the specified primary construction material (concrete, metal, or wood) are shown in Figure 1.

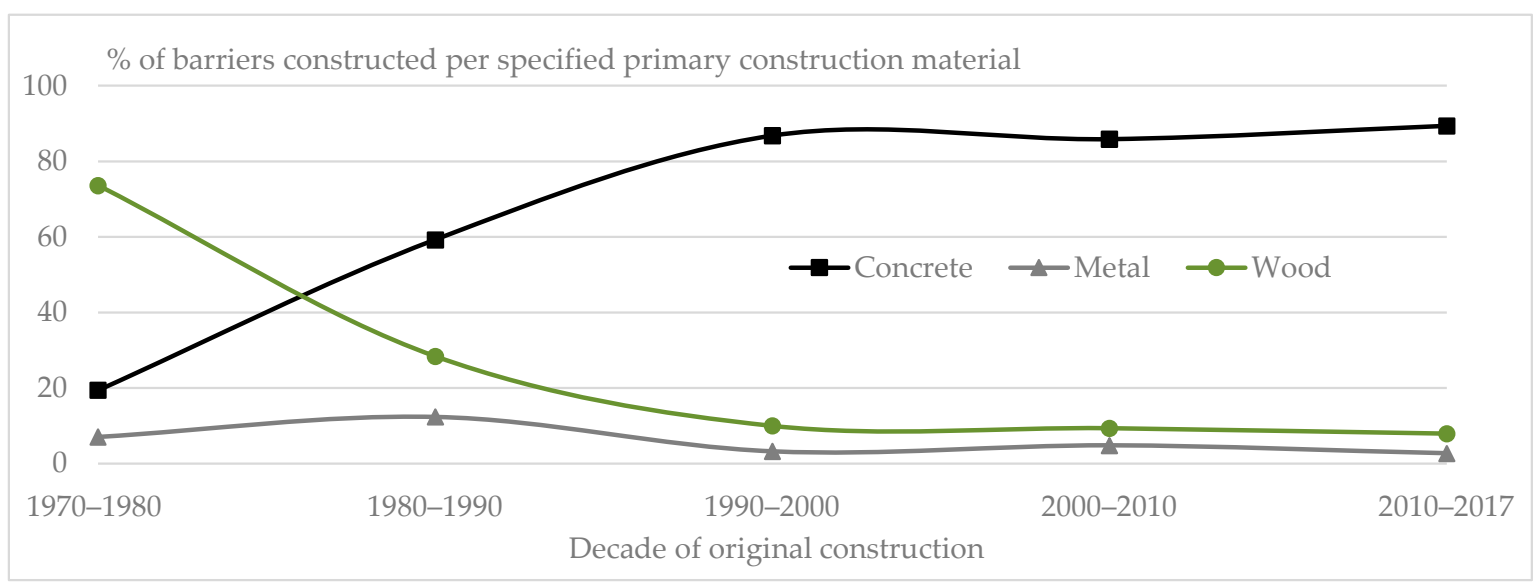

Figure 1. Panel material trends during the last five decades of road traffic noise wall construction (from 1973 to 2017).

It is clear from the Figure 1 that the trend in the choice of materials shifted completely from wood to concrete panels in the last decades, even though, from a sustainability point of view, concrete panels' cradle-to-gate carbon footprints are the worst among the observed types of panels. According to previous research, if the entire lifecycle is considered, the main environmental impact of concrete panels is related to the production processes of the binder and, to a lesser extent, the aggregate. A possible way to reduce the environmental impact of the production of concrete is to use secondary raw materials as source materials for concrete, either as binders (pulverized fly ash or ground granulated blast furnace slag) or as aggregates (polyurethane foam scrap, iron-free tire rubber granulate, mixed plastics aggregate, or expanded mixed plastics) [57-60]. In addition, as the lowest minimal average values were reported for the sound absorption of concrete panels, further investigations should be focused on the characteristics of absorbing lightweight concrete panels.

\subsubsection{Lightweight Concrete Panels}

Currently, sound absorbing (porous) lightweight concrete is a common material for the construction of the sound absorbing non-structural layers of concrete noise walls, and its noise abatement characteristics and applications in civil engineering fields have been researched in detail [61-69].

Lightweight concrete is defined as concrete with an oven-dry density between 800 and $2000 \mathrm{~kg} / \mathrm{m}^{3}$. This property is achieved either by replacing dense natural aggregates with lightweight aggregates (lightweight aggregate concrete), by inducing voids within the concrete, or by eliminating the fine aggregate from the concrete mix $[70,71]$. The porosity of this type of concrete is achieved by creating open voids in the material that are developed by either removing or reducing the fine aggregates and lowing the binder contents. While sound waves propagate in these open voids, their energy is changed to heat energy, thus reducing the noise at the receiver end [64].

Lightweight aggregates used in the production of lightweight concrete are defined as any aggregates with a particle density of less than $2.0 \mathrm{Mg} / \mathrm{m}^{3}$ or a dry loose bulk density of less than $1200 \mathrm{~kg} / \mathrm{m}^{3}$ [70]. Lightweight aggregates can be divided into two groups: 
those that are ready to use only with mechanical treatment, i.e., crushing, cutting, grinding, and sieving (such as pumice, diatomite, scoria, volcanic cinders, waste rubber granules, and plastic granules) and those whose production requires thermal treatments (like expanded clay, shale, slate, slag, diatomaceous shale, perlite, and vermiculite) [71,72].

From a noise-wall sustainability perspective, there remains a large selection of aggregates used in the manufacture of absorbing porous layers of the concrete wall panels facing the carriageway. The next section gives a more detailed review of the characteristics of materials used in the production of lightweight concrete panels.

\subsubsection{Lightweight Aggregate Types}

Lightweight expanded clay aggregates and lightweight plant biomass aggregates are common types of lightweight aggregates used today in the production of the sound absorbing, non-structural layer of noise walls. The use of recycled tire rubber aggregates as a sustainable solution to produce lightweight concrete has received increasing attention in recent years $[60,73-77]$.

Lightweight expanded clay aggregates are produced from special plastic clay with no or very little lime content. In the production process, the clay is dried, heated, and burned in rotary kilns at $1100-1300^{\circ} \mathrm{C}$. Gas is released inside the pellets during heating and entrapped in the pellets during cooling, while the organic compounds burn off, forcing the pellets to expand. This process results in the production of ceramic pellets with porous, lightweight, and high crushing resistance properties, as well as a uniform pore structure and round shape due to the kiln's circular movement. Lightweight expanded clay aggregates can have different sizes suitable for fine or coarse aggregates [78,79].

Lightweight plant biomass aggregates include waste produced by timber industries obtained from the cutting, sawing, or grinding of timber in the form of particles (hardwood or softwood sawdust, shavings, trimmings, and bark) or wood chips produced from roundwood logs. Wood is a highly porous and very durable material that needs to be treated before being used as an aggregate. Untreated plant biomass affects the hardening process of the cement, resulting in mixtures that have great difficulties in obtaining a fixed composition [80-83].

Recycled tire rubber aggregates are produced through the processing of end-of-life vehicle tires by a mechanical pulverization process or by a cryogenic pulverization process. The production of pulverized tires by the mechanical pulverization process includes three steps of mechanical size reduction, wherein the tires are torn to pieces and, through gradual grinding, undergo a separation process. In this process, the basic components of vehicle tires (rubber parts, steel, and textile fibers) are separated. After that, the rubber parts enter a granulator where they are processed into aggregates of different gradings. The production of pulverized tires by the cryogenic pulverization process includes two steps of mechanical size reduction. The first step is mechanical size reduction, and the second step is a further size reduction to the pulverized material under cryogenic conditions, through which it is easier to obtain the desired particle size [57,60,84].

The noise walls presented and compared in the following paragraphs include Liadur, Faseton, and RUCONBAR. Liadur is a noise wall whose panels incorporate lightweight concrete from the Liapor MLB 2 aggregate $\left(750 \mathrm{~kg} / \mathrm{m}^{3}\right)$ in the absorption layer. Liapor is a lightweight aggregate with a German trademark and origin. While manufactured from an argillaceous resource of excavated shale in Germany, expanded clay is used under license in the production of Liapor MLB 2 aggregates [78]. The sound absorptive layers of Faseton noise wall panels are made from wooden cement that contains wood chips of various sizes. RUCONBAR was developed by The Faculty of Civil Engineering at the University of Zagreb during a project that was conducted under the umbrella of the Eco-Innovation initiative and the Executive Agency for the Competitiveness and Innovation Framework Programme (CIP). RUCONBAR panels have a sound absorptive layer that contains $40 \%$ rubber granules obtained through a waste tire mechanical recycling process [75]. 


\subsubsection{Acoustic Characteristics}

From a traffic noise management and abatement perspective, the most important property of the described noise walls is their ability to absorb noise. Testing of their absorbing properties in accordance with the standards HRN EN ISO 354:2004 and HRN EN 1793-1:1999 was conducted on samples of the abovementioned systems in the scope of the RUCONBAR project in 2013. The analyzed samples had similar absorbing surface crosssections and absorbing layers $10 \mathrm{~cm}$ in thickness. According to the measurement results, all three analyzed noise wall panels are listed under the A2 class of sound absorption based on a sound absorption value ranging from 4.4 to $7 \mathrm{~dB}[73,74]$. Higher classes of sound absorption are achieved when various cross-sections of the absorption surface are used, as shown in Table 1 [85-87].

Table 1. Classes of sound absorption for various cross-sections of the absorption surface.

\begin{tabular}{ccccc}
\hline Product & Shape of Surface & Absorbing Layer Thickness $(\mathbf{c m})$ & DL $_{\boldsymbol{\alpha}}(\mathbf{d B})$ & Sound Absorption Class $^{\mathbf{1}}$ \\
\hline \multirow{4}{*}{ Liadur } & flat & 15 & 8 & $\mathrm{~A} 3$ \\
& low wave & 11 & 8 & $\mathrm{~A} 3$ \\
& medium wave & 13 & 10 & $\mathrm{~A} 3$ \\
& high wave & 22 & 16 & $\mathrm{~A} 5$ \\
Faseton & block & 7,9 & 10 & $\mathrm{~A} 3$ \\
& low wave & 11 & 18 & $\mathrm{~A} 3$ \\
& high wave & 12 & 15 & $\mathrm{~A} 5$ \\
RUCONBAR & mushroom & 16 & 6 & $\mathrm{~A} 4$ \\
& flat & 20 & 9 & $\mathrm{~A} 2$ \\
& trapezoidal & 13 & 9 & $\mathrm{~A} 3$ \\
& high wave & 12 & $\mathrm{~A} 3$ \\
\hline
\end{tabular}

${ }^{1} \mathrm{~A} 2: 4-7 \mathrm{~dB}, \mathrm{A3}: 8-11 \mathrm{~dB}, \mathrm{~A} 4:$ 12-15 dB; A5: >15 dB.

\subsubsection{Cradle-to-Gate Sustainability}

Previous studies have shown that the $\mathrm{CO}_{2}$-eq emission factors of manufacturing concrete components for the analysed noise walls are as follows. The $\mathrm{CO}_{2}$-eq emission factor for wood chips produced from roundwood logs is $7.9 \mathrm{~g} \mathrm{CO}_{2}$-eq $/ \mathrm{kg}$ [88], that for expanded clay aggregates amounts to $320 \mathrm{~g} \mathrm{CO}_{2}-\mathrm{eq} / \mathrm{kg}$ [59], and that for mechanically pulverized scrap tires amounts to $122 \mathrm{~g} \mathrm{CO}_{2}$-eq $/ \mathrm{kg}$ [84].

Research conducted in [59] showed that the carbon footprint of $1 \mathrm{~m}^{3}$ of concrete blocks (density of 1000 to $1400 \mathrm{~kg} / \mathrm{m}^{3}$ ) with the expanded clay aggregate Liapor amounts to $290 \mathrm{~kg} \mathrm{CO}$-eq based on a cradle-to-gate assessment and that the energy consumption of clay expansion is largely responsible for this value. At the same time, the carbon footprint of concrete blocks with tire rubber aggregates amounts to $205 \mathrm{~kg} \mathrm{CO}_{2}$-eq.

\section{Data Analysis and Evaluation}

The review of the available research results and technical information on the acoustic and non-acoustic characteristics, long-term performance, and technical and economic sustainability of noise walls (which is described in Section 2) resulted in a collection of data with highly dispersed values. This data were then systematized for further meta-analysis. The minimal reported values of the acoustic and non-acoustic characteristics, long-term performance, and technical and economic sustainability of the panels were identified.

The minimal values of the acoustic characteristics for the analyzed types of panels are reported in $[51,53,73]$. It should be noted that the acoustic performance of the panels strongly depends not only on their materials but also on the thickness of their absorbing layer, their texture, and the cross-sections of their surfaces [89] (flat, trapezoid, or undulating (low or high waves)).

The different mechanical and stability characteristics of concrete, metal, and wood noise walls limit the possibilities of their application, affect their construction procedures, and, consequently, impact their costs. The minimal values of non-acoustic character- 
istics, technical characteristics, and reported average procurement and overall average construction costs in $€ / \mathrm{m}^{2}$ for each considered panel type constructed in Europe are reported in $[44,53,90]$.

The minimal expected service lives of panels made of different materials, their maintenance and replacement, and their lifecycle costs are reported in [44,51]. Reported cost data correspond well with previous research performed in [37], where it was concluded that the two most important variables in determining lifecycle costs for noise walls are the initial construction cost and service life and the costs of maintenance activities remaining small compared to the cost of noise wall construction and replacement.

Metal aluminum and steel panels, as well as wood timber and willow panels, were considered separately in a further analysis because the review showed that there were significant differences between their minimal service life and (cradle-to-gate) carbon and water footprints reported in [44].

The identified minimal values of the specific noise wall performance measurements for each analyzed panel type are presented in Table 2.

For the multicriterial evaluation of concrete, metal, and wood panels, the limit values of each performance criterion that define the score from 1 to 5 were chosen (Table 3). The limit value choice was based on the prescribed and/or desired performance identified during the literature review. Each panel type was assigned a score based on the collected data for minimally achievable performance given in Table 2 and the defined ranges given in Table 3. The defined scores from 1 to 5 are presented in Table 4. Figure 2 shows the calculated average score for each performance group and the overall average score for each panel type.

Table 2. Overview of the minimal reported values of the specific noise wall performance measures for each analyzed panel type.

\begin{tabular}{|c|c|c|c|c|c|c|}
\hline \multirow{2}{*}{ Performance Group } & \multirow{2}{*}{$\begin{array}{c}\text { Noise Walls Panel } \\
\text { Performance Measure }\end{array}$} & \multirow{2}{*}{ Concrete } & \multicolumn{2}{|c|}{ Metal } & \multicolumn{2}{|c|}{ Wood } \\
\hline & & & Aluminum & Steel & Timber & Willow \\
\hline \multirow{3}{*}{ Acoustic performance } & $\begin{array}{l}\text { Single-number rating of sound } \\
\text { absorption }(\mathrm{dB})\end{array}$ & $4[73]$ & \multicolumn{2}{|c|}{8 [53] } & \multicolumn{2}{|c|}{8 [73] } \\
\hline & $\begin{array}{l}\text { Single-number rating of sound } \\
\text { insulation }(\mathrm{dB})\end{array}$ & $24[73]$ & \multicolumn{2}{|c|}{$15[53]$} & \multicolumn{2}{|c|}{24 [73] } \\
\hline & Insertion loss $(\mathrm{dB}(\mathrm{A}))$ & 18 [51] & \multicolumn{2}{|c|}{19 [51] } & \multicolumn{2}{|c|}{13 [51] } \\
\hline \multirow{3}{*}{$\begin{array}{l}\text { Non-acoustic } \\
\text { performance }\end{array}$} & Surface density $\left(\mathrm{kg} / \mathrm{m}^{2}\right)$ & $150-250[90]$ & $5-20[90]$ & $5-10[90]$ & $<20[90]$ & $<5[44]$ \\
\hline & Mechanical resistance $\left(\mathrm{kg} / \mathrm{m}^{2}\right)$ & $>500[53]$ & \multicolumn{2}{|c|}{$<400[53]$} & \multicolumn{2}{|c|}{$>20[90]$} \\
\hline & Average construction costs $\left(€ / \mathrm{m}^{2}\right)$ & $225[44]$ & \multicolumn{2}{|c|}{$216[44]$} & \multicolumn{2}{|c|}{$206[44]$} \\
\hline \multirow{4}{*}{$\begin{array}{l}\text { Long-term } \\
\text { performance }\end{array}$} & Minimal service life (years) & $40[44]$ & $30[44]$ & $20-25[44]$ & $20-40$ [44] & $25[44]$ \\
\hline & $\begin{array}{l}\text { Maintenance and replacement } \\
\qquad \operatorname{costs}\left(€ / \mathrm{m}^{2}\right)\end{array}$ & $40[51]$ & \multicolumn{2}{|c|}{$120[51]$} & \multicolumn{2}{|c|}{115 [51] } \\
\hline & Lifecycle cost $\left(€ / \mathrm{m}^{2}\right)$ & $305[51]$ & \multicolumn{2}{|c|}{$515[51]$} & \multicolumn{2}{|c|}{$360[51]$} \\
\hline & Carbon footprint $(\mathrm{t})$ & $70[44]$ & $0.7[44]$ & $60[44]$ & $4[44]$ & $-17[44]$ \\
\hline \multirow{4}{*}{$\begin{array}{l}\text { Cradle-to-Gate } \\
\text { Sustainability and } \\
\text { Recyclability }\end{array}$} & Water footprint $\left(10^{6} 1\right)$ & $0.8[44]$ & $270[44]$ & $270[44]$ & $0.5[44]$ & $850[44]$ \\
\hline & Primary energy use $\left(10^{9} \mathrm{~J}\right)$ & $3.7[44]$ & $1.2[44]$ & $0.8[44]$ & $0.1[44]$ & $1.9[44]$ \\
\hline & $\begin{array}{c}\text { Transportation embodied } \\
\text { energy }\left(10^{9} \mathrm{~J}\right)\end{array}$ & $0.4[44]$ & $0.05[44]$ & $0.05[44]$ & $0.01[44]$ & $0.1[44]$ \\
\hline & Recycling potential at end-of-life (\%) & $80[44]$ & $100[44]$ & $100[44]$ & $20[44]$ & $40[44]$ \\
\hline
\end{tabular}


Table 3. Limit values (score from 1 to 5) of each wall panel performance measure.

\begin{tabular}{|c|c|c|c|c|c|c|}
\hline \multirow{2}{*}{ Performance Group } & \multirow{2}{*}{$\begin{array}{l}\text { Noise Walls Panel } \\
\text { Performance Measure }\end{array}$} & \multicolumn{5}{|c|}{ Score ${ }^{1}$} \\
\hline & & 5 & 4 & 3 & 2 & 1 \\
\hline \multirow{3}{*}{ Acoustic performance } & $\begin{array}{l}\text { Single-number rating of sound } \\
\text { absorption }(\mathrm{dB})\end{array}$ & $>11$ & 8-10 & $4-7$ & $<4$ & no aps. \\
\hline & $\begin{array}{l}\text { Single-number rating of sound } \\
\text { insulation }(\mathrm{dB})\end{array}$ & $\geq 24$ & $23-20$ & $15-19$ & $<15$ & no isol. \\
\hline & Insertion loss $(\mathrm{dB}(\mathrm{A}))$ & $\geq 20$ & $15-19$ & $14-10$ & $9-5$ & $<4$ \\
\hline \multirow{4}{*}{ Non-acoustic performance } & Surface density $\left(\mathrm{kg} / \mathrm{m}^{2}\right)$ & $>150$ & $150-100$ & $100-50$ & $50-20$ & $<20$ \\
\hline & Mechanical resistance $\left(\mathrm{kg} / \mathrm{m}^{2}\right)$ & $>500$ & $500-250$ & $250-120$ & $120-20$ & $<20$ \\
\hline & Average construction costs $\left(€ / \mathrm{m}^{2}\right)$ & $<200$ & $200-210$ & $210-220$ & $220-230$ & $>230$ \\
\hline & Minimal service life (years) & $>40$ & $30-40$ & $20-30$ & $10-20$ & $<10$ \\
\hline \multirow[t]{2}{*}{ Long-term performance } & $\begin{array}{l}\text { Maintenance and replacement } \\
\text { costs }\left(€ / \mathrm{m}^{2}\right)\end{array}$ & $<50$ & 50-75 & $75-100$ & $100-125$ & $>125$ \\
\hline & Lifecycle cost $\left(€ / \mathrm{m}^{2}\right)$ & $<300$ & $300-350$ & $350-400$ & $400-450$ & $>450$ \\
\hline \multirow{5}{*}{$\begin{array}{l}\text { Cradle-to-Gate } \\
\text { Sustainability and } \\
\text { Recyclability }\end{array}$} & Carbon footprint $(\mathrm{t})$ & $<0$ & $0-20$ & $20-40$ & $40-60$ & $>60$ \\
\hline & Water footprint $\left(10^{6} 1\right)$ & $<200$ & $200-400$ & $400-600$ & $600-800$ & $>800$ \\
\hline & Primary energy use $\left(10^{9} \mathrm{~J}\right)$ & $<1$ & $1-2$ & $2-3$ & $3-4$ & $>4$ \\
\hline & Transportation embodied energy $\left(10^{9} \mathrm{~J}\right)$ & $<0.1$ & $0.1-0.2$ & $0.2-0.3$ & $0.3-0.4$ & $>0.4$ \\
\hline & Recycling potential at end-of-life (\%) & $100-80$ & $80-60$ & $60-40$ & $40-20$ & $20-0$ \\
\hline
\end{tabular}

Table 4. Noise wall panel performance measure score by panel material type.

\begin{tabular}{|c|c|c|c|c|c|c|}
\hline \multirow{2}{*}{ Performance Group } & \multirow{2}{*}{$\begin{array}{l}\text { Noise Walls Panel } \\
\text { Performance Measure }\end{array}$} & \multirow{2}{*}{ Concrete } & \multicolumn{2}{|c|}{ Metal } & \multicolumn{2}{|c|}{ Wood } \\
\hline & & & Aluminum & Steel & Timber & Willow \\
\hline \multirow{2}{*}{ Acoustic performance } & $\begin{array}{l}\text { Single-number rating of sound } \\
\text { absorption }(\mathrm{dB})\end{array}$ & 3 & 4 & 4 & 4 & 4 \\
\hline & $\begin{array}{l}\text { Single-number rating of sound } \\
\text { insulation }(\mathrm{dB})\end{array}$ & 5 & 3 & 3 & 5 & 5 \\
\hline \multirow{5}{*}{ Non-acoustic performance } & Insertion loss $(\mathrm{dB}(\mathrm{A}))$ & 4 & 4 & 4 & 3 & 3 \\
\hline & Surface density $\left(\mathrm{kg} / \mathrm{m}^{2}\right)$ & 5 & 1 & 1 & 1 & 1 \\
\hline & Mechanical resistance $\left(\mathrm{kg} / \mathrm{m}^{2}\right)$ & 5 & 4 & 4 & 2 & 2 \\
\hline & Average construction costs $\left(€ / \mathrm{m}^{2}\right)$ & 2 & 3 & 3 & 4 & 4 \\
\hline & Minimal service life (years) & 5 & 5 & 4 & 5 & 3 \\
\hline Long-term performance & $\begin{array}{l}\text { Maintenance and replacement } \\
\text { costs }\left(€ / \mathrm{m}^{2}\right)\end{array}$ & 5 & 2 & 2 & 2 & 2 \\
\hline \multirow{6}{*}{$\begin{array}{l}\text { Cradle-to-Gate } \\
\text { Sustainability and } \\
\text { Recyclability }\end{array}$} & Lifecycle cost $\left(€ / \mathrm{m}^{2}\right)$ & 4 & 1 & 1 & 3 & 3 \\
\hline & Carbon footprint $(\mathrm{t})$ & 1 & 4 & 2 & 2 & 5 \\
\hline & Water footprint $\left(10^{6} 1\right)$ & 5 & 4 & 4 & 5 & 1 \\
\hline & Primary energy use $\left(10^{9} \mathrm{~J}\right)$ & 2 & 4 & 5 & 5 & 4 \\
\hline & Transportation embodied energy $\left(10^{9} \mathrm{~J}\right)$ & 2 & 5 & 5 & 5 & 4 \\
\hline & Recycling potential at end-of-life $(\%)$ & 4 & 5 & 5 & 1 & 2 \\
\hline \multicolumn{2}{|c|}{ Average overall score for panel material type } & 3.7 & 3.5 & 3.4 & 3.4 & 3.1 \\
\hline
\end{tabular}

The conducted analysis showed that concrete panels have the highest average scores for every performance group besides cradle-to-gate sustainability, as well as the highest overall average score. The cradle-to-gate sustainability score of concrete panels is worse due to the large carbon footprint of their production. This result initiated a comprehensive cradle-to-grave assessment of concrete panels made with lightweight concrete using expanded clay and a recycled tire rubber aggregate. This analysis was performed to identify opportunities for improvement in lightweight concrete sustainability by quantifying the impacts that each product has on the environment throughout its full lifecycle, from production and manufacturing to the disposal phase. Since the $\mathrm{CO}_{2}$-eq emission factor for wood chips is considerably lower than that for the expanded clay and rubber aggregate, 
the lightweight concrete panel solution with a wood cement absorbing layer containing wood chips of various sizes from debarked wood was excluded from further comparisons.

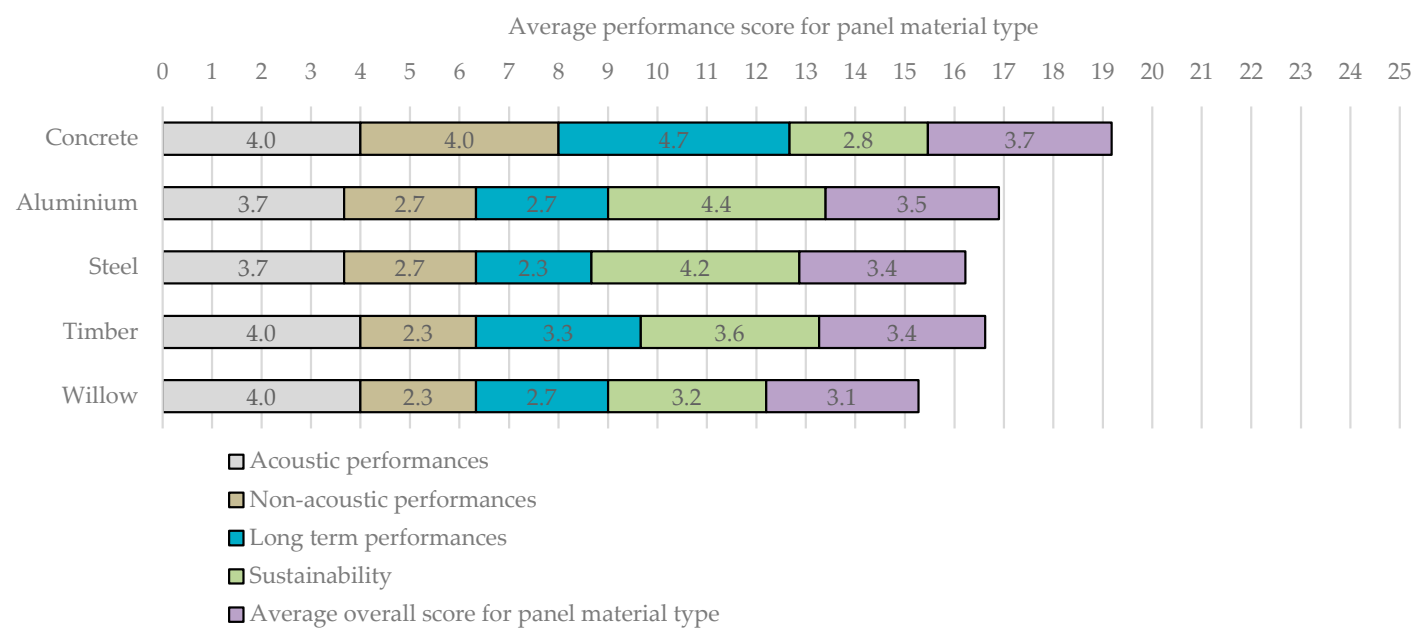

Figure 2. Average performance scores by panel material type.

Previous research conducted in [59] showed that the carbon footprint of concrete blocks with expanded clay aggregate Liapor in a cradle-to-grave assessment amounts to $1000 \mathrm{~kg} \mathrm{CO}$-eq. At the same time, the carbon footprint of concrete blocks with tire rubber aggregates amounts to $200 \mathrm{~kg} \mathrm{CO}_{2}$-eq. The greenhouse gas emissions caused by the incineration of tire rubber were added for the concrete blocks using an expanded clay aggregate, which increased the aggregate's carbon footprint by more than a factor of three.

A cradle-to-grave comparative lifecycle assessment of noise protection wall panels with expanded clay (Liadur) and rubber granules (RUCONBAR) was conducted on the RUCONBAR prototype optimization process. Panels that were analyzed had an average absorption layer thickness of $7 \mathrm{~cm}$ and identical structural layers. The performed analysis did not include fuel consumption and emissions for the heat production in manufacturing facility, nor did it include sanitary water consumption, fuel consumption for the inner transportation of lift trucks, or the production of machines involved in the production process. No allocation procedure or partitioning of energy supply between the other product systems at the location was considered, and the only considered impact from 20-year usage involved the wall's transport to the location of installation (the chosen distance was $100 \mathrm{~km}$, and the transport was conducted by a heavy truck of $24 \mathrm{t}$ ).

The analysis showed that the main contributions to the carbon footprint from the panels were due to their production processes (Table 5), which included the acquisition and production of raw materials and their transport to the relevant location, while the maintenance and disposal processes had a significantly smaller impact. In this analysis, recycled rubber was not included in the inventory as an input material. Instead, it was considered as the final product for recycling end-of-life tires. Thus, only the energy consumption of the mechanical grinding process and transport to the production site of the noise protection wall was included. For the disposal of walls, the most probable scenario was assumed, where $90 \%$ of the construction waste produced in Croatia was still landfilled. For RUCONBAR, we used a disposal scenario where $90 \%$ of the absorption layer is recycled and reused for a new absorption layer.

Due to the significant proportion of cement in the supporting layer, for both wall types, a sensitivity analysis was conducted using different types of cement, with constant parameters used for additional materials. By using cement types such as blast furnace slag cement, containing $4 \%$ cement, 50\% iron slag from blast furnaces, and $46 \%$ clinker, a significant reduction in the overall environmental impact was observed. For LIADUR, global warming potential (GWP) was reduced from 120 to $99 \mathrm{~kg} \mathrm{CO}$-eq/ $\mathrm{m}^{2}$, while for the RUCONBAR, the GWP decreased from 117 to $94 \mathrm{~kg} \mathrm{CO}_{2}$-eq $/ \mathrm{m}^{2}$. 
Table 5. Comparison of the carbon footprint of panels.

\begin{tabular}{|c|c|c|}
\hline Process & Liadur Greenhouse Gasses (kg CO & RUCONBAR Greenhouse Gasses $\left(\mathrm{kg} \mathrm{CO}_{2}\right.$-eq) \\
\hline Production & 112 & 107 \\
\hline Use & 5.3 & 6.3 \\
\hline Disposal & 3.3 & 2.9 \\
\hline Total & 120.6 & 116.2 \\
\hline
\end{tabular}

The results of this environmental assessment showed a lower environmental load for the noise protection wall with recycled rubber. As both types of noise walls use the same structural layer, the absorption layer determined this outcome. The comparative analysis of this element as an independent unit is outlined in Table 6. In this analysis, the environmental benefits from using recycled rubber, such as avoiding impacts from the disposal processes of old tires, were not considered.

Table 6. Comparison of the GWP of the absorption layer.

\begin{tabular}{|c|c|c|}
\hline Process & Liadur GWP (kg CO $\left.2-e q / m^{2}\right)$ & RUCONBAR GWP $\left(\mathrm{kg} \mathrm{CO} \mathrm{CO}_{2}-\mathrm{eq} / \mathrm{m}^{2}\right)$ \\
\hline Manufacturing & 27.54 & 23.03 \\
\hline Transport to location & 0.85 & 1.90 \\
\hline Disposal & 0.53 & 0.12 \\
\hline Total & 28.92 & 25.05 \\
\hline
\end{tabular}

\section{Discussion}

Among the observed panels, concrete panels have the highest mechanical resistance, longest service life, lowest lifecycle costs, and lowest water footprint. They also address all the required safety characteristics very well, i.e., they provide good fire resistance (with practically no toxic gases or wind-borne ember emissions in the case of a fire), have no light reflection (glare that can disturb road users is a common problem for metal panels), and possess only a small risk of falling debris in the case of a vehicle impact (they do not shatter like metal or wood panels). Furthermore, analysis of the historical data on the application of different types of noise walls showed that the choice of materials used in the production of panels shifted completely from wood to concrete in recent decades. Consequently, further investigations were focused on the concrete panel characteristics, specifically for panels with sound absorptive layers made with commonly used lightweight aggregates (expanded clay and plant biomass) and recycled tire rubber aggregates.

Based on the available data, the carbon footprints of concrete blocks with expanded clay aggregate are five times higher than the carbon footprints of concrete blocks with tire rubber aggregates in the cradle-to-grave approach. At the same time, the cradle-to-grave approach in a comparative lifecycle assessment of panels with an average absorption layer thickness of $7 \mathrm{~cm}$ and an identical structural layer resulted in significantly smaller differences in carbon footprints. This was caused by the exclusion of the environmental benefits from using recycled rubber (avoiding impacts from the disposal processes of old tires) from the analysis.

The results of the performed analysis are based mainly on publicly available data on noise walls constructed in Northern and Central Europe and the United States and, as such, may not be specific enough to give detailed insights into South European practices and experiences. To provide better insight into the service life efficiency of noise walls and panels and to improve the process of noise wall design and management in South European countries, further data analysis of panel production, application, and disposal will be conducted while focusing on those countries. Moreover, to further investigate the potential benefits and limitations of lightweight concrete panel application, the influence of the shape and thickness of the sound absorptive layer on the acoustic properties of these panels, as well as the impact of climate change on their durability, should be addressed in detail. 


\section{Conclusions}

Noise wall panels can be systematized based on the primary material used in their production considering four basic types: concrete, metal, wood, and transparent. The choice of panel material plays an important role in the overall sustainability of the noise wall, so it is necessary to have all relevant information on the characteristics of these materials and panels (as the final element of the noise wall) in the noise wall design phase. The research presented in this paper aimed to reduce uncertainty in the selection of panel materials and types and support the process of road noise management in southern European countries by shifting the emphasis in decision making from the price to the long-term sustainability of the entire road traffic noise protection project.

An overview and systematization of the data and a multicriterial evaluation of the characteristics of concrete, metal, and wood panels showed that concrete panels have the highest overall average score. They also have the highest average score for their acoustic properties, non-acoustic properties, and long-term performance. These panels have a lower score for cradle-to-gate sustainability because of their high carbon footprint. At the same time, metal panels have the lowest transportation embodied energy and are highly recyclable at end-of-life, while wood panels' average construction costs and primary energy use are the lowest. Further analysis showed that the main contributions to the carbon footprint of the concrete panels are due to their production processes, while the maintenance and disposal processes have a significantly smaller impact. For foreign experiences in noise wall construction and maintenance, the current market, and the infrastructure share, it is safe to assume that when choosing the materials for panels, preference should be given to concrete. The best way to indirectly reduce concrete panels' life-time carbon footprints in the design process is to use panels made with aggregates from secondary raw materials, such as recycled tire aggregates.

Author Contributions: Conceptualization, M.A. and S.L.; methodology, M.A. and S.L.; data collection, M.A. and S.A.; data analysis, M.A. and S.A.; writing-original draft preparation, M.A. and S.A.; writing-review and editing, S.L.; supervision, S.L.; funding acquisition, S.L. All authors have read and agreed to the published version of the manuscript.

Funding: Part of this research was performed in the scope of the project RUCONBAR-Rubberized concrete noise barriers, under the umbrella of the Eco-Innovation initiative and Executive Agency for Competitiveness and Innovation (CIP) framework, Contract number ECO/10/277317/SI2.595674.

Institutional Review Board Statement: Not applicable.

Informed Consent Statement: Not applicable.

Data Availability Statement: Data sharing not applicable.

Conflicts of Interest: The authors declare no conflict of interest.

\section{References}

1. European Environment Agency (EEA). Managing Exposure to Noise in Europe. Briefing January 2017. Available online: https:/ / www.eea.europa.eu/publications / managing-exposure-to-noise-in-europe (accessed on 2 May 2020).

2. Muzet, A. Environmental noise, sleep and health. Sleep Med. Rev. 2007, 11, 135-142. [CrossRef] [PubMed]

3. Zacarías, F.F.; Molina, R.H.; Ancela, J.L.C.; López, S.L.; Ojembarrena, A.A. Noise exposure in preterm infants treated with respiratory support using neonatal helmets. Acta Acust. United Acust. 2013, 99, 590-597. [CrossRef]

4. Hygge, S.; Evans, G.W.; Bullinger, M. A prospective study of some effects of aircraft noise on cognitive performance in schoolchildren. Psychol. Sci. 2002, 13, 469-474. [CrossRef] [PubMed]

5. Lercher, P.; Evans, G.W.; Meis, M. Ambient noise and cognitive processes among primary schoolchildren. Environ. Behav. 2003, 35, 725-735. [CrossRef]

6. Chetoni, M.; Ascari, E.; Bianco, F.; Fredianelli, L.; Licitra, G.; Cori, L. Global noise score indicator for classroom evaluation of acoustic performances in LIFE GIOCONDA project. Noise Mapp. 2016, 3, 157-171. [CrossRef]

7. Dratva, J.; Phuleria, H.C.; Foraster, M.; Gaspoz, J.-M.; Keidel, D.; Künzli, N.; Liu, L.-J.S.; Pons, M.; Zemp, E.; Gerbase, M.W.; et al. Transportation noise and blood pressure in a population-based sample of adults. Environ. Health Perspect. 2012, 120, 50-55. [CrossRef] 
8. Babisch, W.; Beule, B.; Schust, M.; Kersten, N.; Ising, H. Traffic noise and risk of myocardial infarction. Epidemiology 2005, 16, 33-40. [CrossRef]

9. Babisch, W.; Swart, W.; Houthuijs, D.; Selander, J.; Bluhm, G.; Pershagen, G.; Dimakopoulou, K.; Haralabidis, A.S.; Katsouyanni, K.; Davou, E. Exposure modifiers of the relationships of transportation noise with high blood pressure and noise annoyance. J. Acoust. Soc. Am. 2012, 132, 3788-3808. [CrossRef]

10. Miedema, H.M.E.; Oudshoorn, C.G.M. Annoyance from transportation noise: Relationships with exposure metrics DNL and DENL and their confidence intervals. Environ. Health Perspect. 2001, 109, 409-416. [CrossRef]

11. Licitra, G.; Fredianelli, L.; Petri, D.; Vigotti, M.A. Annoyance evaluation due to overall railway noise and vibration in Pisa urban areas. Sci. Total Environ. 2016, 568, 1315-1325. [CrossRef]

12. Directive 2002/49/EC of the European Parliament and of the Council of 25 June 2002 Relating to the Assessment and Management of Environmental Noise (END). Available online: http:/ / data.europa.eu/eli/dir/2002/49/2020-03-25 (accessed on 2 May 2020).

13. Dragčević, V.; Lakušić, S.; Ahac, S.; Ahac, M. Contribution to Optimization of Noise Mapping Procedures. GRADEVINAR 2008, 60,787-795.

14. Science for Environment Policy-Noise Abatement Approaches, Future Brief 17. Produced for the European Commission DG Environment by the Science Communication Unit, UWE, Bristol, 2017. Available online: http://ec.europa.eu/scienceenvironment-policy (accessed on 2 May 2020).

15. Zambon, G.; Roman, H.E.; Smiraglia, M.; Benocci, R. Monitoring and Prediction of Traffic Noise in Large Urban Areas. Appl. Sci. 2018, 8, 251. [CrossRef]

16. EEA Glossary. Available online: https://www.eea.europa.eu/help/glossary/eea-glossary/lden (accessed on 7 December 2020).

17. Sandberg, U.; Ejsmont, J. Tyre/Road Noise Reference Book; INFORMEX: Kisa, Sweden, 2002.

18. Licitra, G.; Teti, L.; Cerchiai, M.; Bianco, F. The influence of tyres on the use of the CPX method for evaluating the effectiveness of a noise mitigation action based on low-noise road surfaces. Transp. Res. Part D Transp. Environ. 2017, 55, 217-226. [CrossRef]

19. Bendtsen, H.; Qing, L.; Erwin, K. Acoustic Aging of Asphalt Pavement: A Californian Danish Comparison; Report Number: UCPRCRP-2010-01; The Danish Road Institute-Road Directorate: Hedehusene, Denmark, 2010. [CrossRef]

20. Licitra, G.; Moro, A.; Teti, L.; Del Pizzo, A.; Bianco, F. Modelling of acoustic ageing of rubberized pavements. Appl. Acoust. 2019, 146, 237-245. [CrossRef]

21. Stančerić, I.; Dragčević, V.; Ahac, S. Toward Environmental Noise Estimation according to the Road Surface Characteristics and Traffic Volume. Tech. Gaz. 2010, 17, 191-197.

22. Del Pizzo, A.; Teti, L.; Moro, A.; Bianco, F.; Fredianelli, L.; Licitra, G. Influence of texture on tyre road noise spectra in rubberized pavements. Appl. Acoust. 2020, 159, 107080. [CrossRef]

23. Praticò, F.G. On the dependence of acoustic performance on pavement characteristics. Transp. Res. Part D Transp. Environ. 2014, 29, 79-87. [CrossRef]

24. Bérengier, M.; Stinson, M.; Daigle, G.; Hamet, J. Porous road pavements: Acoustical characterization and propagation effects. J. Acoust. Soc. Am. 1997, 101, 155. [CrossRef]

25. Praticò, F.G.; Anfosso-Lédée, F. Trends and issues in mitigating traffic noise through quiet pavements. Procedia Soc. Behav. Sci. 2012, 53, 203-212. [CrossRef]

26. Kotzen, B.; English, C. Environmental Noise Barriers: A Guide to Their Acoustic and Visual Design, 2nd ed.; Taylor \& Francis: Oxford, UK, 2009.

27. Fredianelli, L.; Del Pizzo, A.; Licitra, G. Recent developments in sonic crystals as barriers for road traffic noise mitigation. Environments 2019, 6, 14. [CrossRef]

28. Jean, P.; Defrance, J. Sound propagation in rows of cylinders of infinite extent: Application to sonic crystals and thickets along roads. Acta Acust. United Acust. 2015, 101, 474-483. [CrossRef]

29. Godinho, L.; Santos, P.G.; Amado-Mendes, P.; Pereira, A.; Martins, M. Experimental and Numerical Analysis of Sustainable Sonic Crystal Barriers Based on Timber Logs. In Proceedings of the EuroRegio2016, Porto, Portugal, 13-15 June 2016.

30. Kay, D.H.; Morgan, S.M.; Bodapati, S.N. Evaluation of Service Life of Noise Barrier Walls in Illinois. Final Report No. ITRC FR97-3 for the Project IIB-H1 FY97. Prepared for the Illinois Department of Transportation-Transportation Research Center. 1999. Available online: https://idot.illinois.gov/Assets/uploads/files/Transportation-System/Research/Illinois-TransportationResearch-Center/1999.11.01\%20-\%20Evaluation\%20of\%20Service\%20Life\%20of\%20Noise\%20Barrier\%20Walls\%20-\%20IIB-H1 \%20FY97.pdf (accessed on 2 May 2020).

31. US Department of Transportation, Federal Highway Administration (FHWA) Technology Exchange Program. Quiet Pavements Systems in Europe. Report No. FHWA-PL-05-011; 2005. Available online: https://international.fhwa.dot.gov/pubs/quiet_pav / p105011.pdf (accessed on 3 May 2020).

32. Joynt, J.L.R. A Sustainable Approach to Environmental Noise Barrier Design. Ph.D. Thesis, School of Architecture, University of Sheffield, Sheffield, UK, 2005.

33. Oltean-Dumbrava, C.; Watts, G.; Miah, A. Transport infrastructure: Making more sustainable decisions for noise reduction. J. Clean. Prod. 2013, 42, 58-68. [CrossRef]

34. Oltean-Dumbrava, C.; Watts, G.; Miah, A. Towards a more sustainable surface transport infrastructure: A Case study of applying multi criteria analysis techniques to assess the sustainability of transport noise reducing devices. J. Clean. Prod. 2016, 112, 2922-2934. [CrossRef] 
35. Oltean-Dumbrava, C.; Miah, A. Assessment and relative sustainability of common types of roadside noise barriers. J. Clean. Prod. 2016, 135, 919-931. [CrossRef]

36. Ohiduzzaman, M.D.; Sirin, O.; Kassem, E.; Rochat, J.L. State-of-the-Art Review on Sustainable Design and Construction of Quieter Pavements-Part 1: Traffic Noise Measurement and Abatement Techniques. Sustainability 2016, 8, 742. [CrossRef]

37. Morgan, S.M.; Kay, D.H. Noise Barrier Material Selection. Transportation Research Record. Paper No. 01-2616. J. Transp. Res. Board 2001. [CrossRef]

38. Conference of European Directors of Roads (CEDR). State of the Art in Managing Road Traffic Noise: Noise Barriers. Technical Report 2017-02. 2017. Available online: https:/ / www.cedr.eu/download/Publications/2017/CEDR-TR2017-02-noise-barriers. pdf (accessed on 14 May 2020).

39. Brero, G. EU Noise Policy: European Noise Barrier Federation (ENBF) Expectations and Contributes. In Proceedings of the "Noise in Europe" Conference, European Commission, Brussels, Belgium, 24 April 2017; Available online: https://ec.europa.eu/ info/events/noise-europe-2017-apr-24_en (accessed on 17 May 2020).

40. Ministry of Sea, Transport, and Infrastructure. Report on Environmental and Social Compliance of the Management and Operations Systems of the Implementing Agencies within the Project "Modernization and Restructuring of the Road Sector" (MARS). 2018. Available online: https://hrvatske-ceste.hr/uploads/documents/attachment_file/file/298/Izvje\%C5\%A1\%C4 \%87e_Mars_npl.pdf (accessed on 12 May 2020). (In Croatian).

41. The Croatian Association of Toll Motorways Concessionaires (HUKA). National Report on Highways. 2018. Available online: http:/ / www.huka.hr/files/docs/HUKA_NI-EN_2018_final.pdf (accessed on 10 July 2020).

42. Vukadin, P. Noise Mitigation Action Plan for the Motorway Concession Area of the Construction and Management Company Rijeka-Zagreb Motorway (ARZ); Rijeka-Zagreb Motorway: Zagreb, Croatia, 2014. (In Croatian)

43. Clairbois, J.P.; de Roo, F.; Garai, M.; Conter, M.; Defrance, J.; Oltean-Dumbrava, C.A.; Durso, C. QUIESST Guidebook to Noise Reducing Devices Optimisation. Report No. FP7-SST-2008-RTD-1. Prepared for the European Community's Seventh Framework Programme (FP7/2007-2013) under Grant Agreement n SCP8-GA-2009-233730. 2012. Available online: https: / / repository.tudelft.nl/view/tno/uuid\%3A16f7a829-5f5c-4523-ab35-1d6cce015cb1 (accessed on 10 June 2020).

44. Oltean-Dumbrava, C.A.; Miah, A.; Watts, G.; Brero, G.; Clairbois, J.P.; Padmos, C.; Auerbach, M.; Hans, J.; Schiopu, N. State of the Art Review and Report on the Sustainability of Noise Reducing Devices QUIESST-Deliverable No.6.1 FP7-SST-2008-RTD-1. In European Community's Seventh Framework Programme; 2010.

45. Conference of European Directors of Roads (CEDR). Noise Management and Abatement. Report 2010-05. 2010. Available online: https: / / www.cedr.eu/download/Publications/2010/e\%20Road\%20noise.pdf (accessed on 10 May 2020).

46. US Department of Transportation, Federal Highway Administration (FHWA), Office of Planning, Environment, \& Realty (HEP). Noise Barriers Inventory. Available online: https:/ / www.fhwa.dot.gov/environment/noise/noise_barriers/inventory/ (accessed on 5 August 2020).

47. European Committee for Standardization (CEN). CEN/TC 226/WG 6-Noise Reducing Devices, Published Standards. Available online: https: / / standards.cen.eu/dyn/www / f?p=204:32:0::::FSP_ORG_ID,FSP_LANG_ID:7542,25\&cs=1563CAC0 058F0284316199F4F140DEE9A (accessed on 10 September 2020).

48. Clairbois, J.P.; Garai, M. The European Standards for Roads and Railways Noise Barriers: State of the Art 2015. In Proceedings of the 10th European Congress and Exposition on Noise Control Engineering: EuroNoise 2015, Maastricht, The Netherlands, 31 May-3 June 2015; pp. 45-50.

49. Shahidan, S.; Hannan, N.I.R.R.; Maarof, M.Z.M.; Leman, A.S.; Senin, M.S. A Comprehensive Review on the Effectiveness of Existing Noise Barriers Commonly Used in the Railway Industry. In MATEC Web Conf. Vol. 87, Proceedings of the 9th International Unimas Stem Engineering Conference (ENCON 2016) "Innovative Solutions for Engineering and Technology Challenges", Sarawak, Malaysia, 26-28 October 2016; Hasan, A., et al., Eds.; EDP Sciences: Les Ulis, France, 2017. [CrossRef]

50. US Department of Transportation, Federal Highway Administration (FHWA), Office of Planning, Environment, \& Realty (HEP). Noise Barrier Design Handbook. Available online: https:/ /www.fhwa.dot.gov/ENVIRonment/noise/noise_barriers/design_ construction/design/design03.cfm (accessed on 4 May 2020).

51. McAvoy, D.S.; Theberge, R. Comparison and Testing of Various Noise Wall Materials; Report No. FHWA/OH-2014/8; The Ohio Department of Transportation, Office of Statewide Planning \& Research: Columbus, OH, USA, 2014.

52. Pigasse, G.; Kragh, J. Optimised Noise Barriers: A State-of-the-Art Report. Report No. 194-2011. Prepared for the VejdirektoratetDanish Road Directorate of Ministry of Transport. 2011. Available online: https://www.vejdirektoratet.dk/udgivelse/optimisednoise-barriers (accessed on 5 May 2020).

53. de la Red Bellvis, E.J. Noise Barriers in Railways-A View on the State of Art. In Proceedings of the RailSpain Congress, Zaragoza, Spain, 14-16 June 2011.

54. Boothby, T.E.; Burroughs, C.B.; Bernecker, C.A.; Manbeck, H.B.; Ritter, M.A.; Grgurevich, S.; Cegelka, S.; Hillbrich Lee, P.D. Design of Wood Highway Sound Barriers. Research Paper FPL-RP-596. Prepared for the United States Department of Agriculture (USDA), Forest Service. 2001. Available online: https:/ / www.fpl.fs.fed.us / documnts /fplrp/fplrp596/fplrp596.pdf (accessed on 10 May 2020). 
55. Ernst, D.; Biton, L.; Reichenbacher, S.; Zgola, M.; Adkins, C. Guidelines for Selection and Approval of Noise Barrier Products. Final Report, Prepared for the National Cooperative Highway Research Program (NCHRP) Project 25-25, Task 40, Transportation Research Board. 2008. Available online: http://onlinepubs.trb.org/onlinepubs/archive/notesdocs/25-25(40)_fr.pdf (accessed on 10 May 2020).

56. Regulation (EU) No 305/2011 of the European Parliament and of the Council of 9 March 2011-Laying Down Harmonised Conditions for the Marketing of Construction Products and Repealing Council Directive 89/106/EEC. Available online: https: / / eur-lex.europa.eu/legal-content/EN/TXT/?uri=CELEX\%3A02011R0305-20140616 (accessed on 10 May 2020).

57. Attanasio, A.; Largo, A.; Larraza Alvarez, I.; Sonzogni, F.; Balaceanu, L. Sustainable aggregates from secondary materials for innovative lightweight concrete products. HERON 2015, 60, 5-26.

58. Visser, J.; Couto, S.; Gupta, A.; Larraza Alvarez, I.; Chozas Ligero, V.; Sotto Mayor, T.; Vinai, R.; Pipilikaki, P.; Largo, A.; Attanasio, A.; et al. Sustainable concrete: Design and testing. HERON 2015, 60, 59-92.

59. van Gijlswijk, R.N.; Pascale, S.; de Vos, S.E.; Urbano, G. Carbon footprint of concrete based on secondary materials. HERON 2015, $60,113-140$.

60. Mushunje, K.; Otieno, M.; Ballim, Y. A review of Waste Tyre Rubber as an Alternative Concrete Consituent Material. In MATEC Web of Conferences vol 199, Proceedings of the 5th International Conference on Concrete Repair, Rehabilitation and Retrofitting (ICCRRR 2018), Cape Town, South Africa, 19-21 November 2018; Alexander, M.G., Beushausen, H., Dehn, F., Moyo, P., Eds.; EDP Sciences: Les Ulis, France, 2018. [CrossRef]

61. Park, S.W.; Seo, D.S.; Lee, J. Studies on the sound absorption characteristics of porous concrete based on the content of recycled aggregate and target void ratio. Cem. Concr. Res. 2005, 35, 1846-1854. [CrossRef]

62. Neithalath, N.; Marolf, A.; Weiss, J.; Olek, J. Modeling the influence of pore structure on the acoustic absorption of enhanced porosity concrete. J. Adv. Concr. Technol. 2005, 3, 29-40. [CrossRef]

63. Cianfrini, C.; Corcione, M.; Fontana, L. Experimental verification of the acoustic performance of diffusive roadside noise barriers. Appl. Acoust. 2007, 68, 1357-1372. [CrossRef]

64. Kim, H.K.; Lee, H.K. Influence of cement flow and aggregate type on the mechanical and acoustic characteristics of porous concrete. Appl. Acoust. 2010, 71, 607-615. [CrossRef]

65. Zhao, C.; Wang, P.; Wang, L.; Liu, D. Reducing Railway Noise with Porous Sound-Absorbing Concrete Slabs. Adv. Mater. Sci. Eng. 2014, 206549. [CrossRef]

66. Carbajo, J.; Esquerdo-Lloret, T.V.; Ramisa, J.; Nadal-Gisbert, A.V.; Denia, F.D. Acoustic properties of porous concrete made from arlite and vermiculite lightweight aggregates. Mater. Construcc. 2015, 65, e072. [CrossRef]

67. Wang, P.; Zhao, C. Study on reducing railway noise by porous concrete sound-absorbing panel. Mater. Res. Innov. 2015, 19, S5-1156-S5-1160. [CrossRef]

68. Zhang, B.; Poon, C.S. Sound insulation properties of rubberized lightweight aggregate concrete. J. Clean. Prod. 2018, 172, 3176-3185. [CrossRef]

69. Rajaonarison, E.F.; Gacoin, A.; Razafindrabe, B.H.N.; Rasamison, V.E. Acoustical properties of lightweight concrete from scoria. Int. J. Curr. Res. 2018, 10, 73667-73674. [CrossRef]

70. Owens, P.L.; Newman, J.B. Lightweight aggregate manufacture. In Advanced Concrete Technology; Newman, J., Choo, B.S., Eds.; Elsevier: Springfield, MO, USA, 2003; pp. 1-12. [CrossRef]

71. Mohammed, J.H.; Hamad, A.J. A classification of lightweight concrete: Materials, properties and application review. Int. J. Adv. Eng. Appl. 2014, 7, 52-57.

72. Kumar, J.D.C.; Arunakanthi, E. The Use of Light Weight Aggregates for Precast Concrete Structural Members. Int. J. Appl. Eng. Res. 2018, 13, 7779-7787.

73. Lakušić, S. How to Obtain EU Project without an EU Partner-Example of RUCONBAR Project From the EU Program CIP ECOInnovation. In Planning, Design, Construction and Renewal in the Civil Engineering, Proceedings of the INDIS 2012, Novi Sad, Serbia, 28-30 November 2012; Radonjanin, V., Folić, R., Lađinović, Đ., Eds.; Faculty of Technical Sciences, Department of Civil Engineering and Geodesy: Novi Sad, Serbia, 2012; pp. 2-15.

74. Lakušić, S.; Bjegović, D.; Haladin, I.; Baričević, A.; Serdar, M. RUCONBAR—Innovative noise protection solution made of recycled waste tyres. Mech. Transp. Commun. 2011, 3, X-76.

75. Serdar, M.; Baričević, A.; Lakušić, S.; Bjegović, D. Special purpose concrete products from waste tyre recyclates. Gradevinar 2013, 65, 793-801.

76. Jedidi, M.; Boulila, A.; Benjeddou, O.; Soussi, C. Crumb Rubber Effect on Acoustic Properties of Self-Consolidating Concrete. Int. J. Therm. Environ. Eng. 2014, 8, 69-76.

77. Holmes, N.; Browne, A.; Montague, C. Acoustic properties of concrete panels with crumb rubber as a fine aggregate replacement. Constr. Build. Mater. 2014, 73, 195-204. [CrossRef]

78. Boarder, R.F.W.; Owens, P.L.; Khatib, J.M. The sustainability of lightweight aggregates manufactured from clay wastes for reducing the carbon footprint of structural and foundation concrete. In Sustainability of Construction Materials, 2nd ed.; Khatib, J.M., Ed.; Woodhead Publishing: Cambridge, UK, 2016; pp. 209-244. [CrossRef]

79. Rashad, A.M. Lightweight expanded clay aggregate as a building material—An overview. Constr. Build. Mater. 2018, 170, 757-775. [CrossRef] 
80. Coatanlem, P.; Jauberthie, R.; Rendell, F. Lightweight wood chipping concrete durability. Constr. Build. Mater. 2006, 20, 776-781. [CrossRef]

81. Macchi, N.; Zwicky, D. Wood-Based Concrete for Composite Building Construction with Timber. In Proceedings of the Concrete Innovation Conference, Oslo, Norway, 11-13 June 2014.

82. Vo, L.T.T.; Navard, P. Treatments of plant biomass for cementitious building materials-A review. Constr. Build. Mater. 2016, 121, 161-176. [CrossRef]

83. Mangi, S.A.; Jamaluddin, N.B.; Siddiqui, Z.; Memon, S.A.; Ibrahim, M.H.B.W. Utilization of Sawdust in Concrete Masonry Blocks: A Review. Mehran Univ. Res. J. Eng. Technol. 2019, 38, 487-494. [CrossRef]

84. Corti, A.; Lombardi, L. End life tyres: Alternative final disposal processes compared by LCA. Energy 2004, 29, 2089-2108. [CrossRef]

85. RUCONBAR. Available online: http://www.ruconbar.com/rcnb/wp-content/uploads/2014/06/RUCONBAR_brochure_A4 EN_web.pdf (accessed on 10 November 2020).

86. LIADUR. Available online: https://www.liadur.cz/cz/vyuzivane-stavebni-materialy-pro-stavbu-protihlukovych-sten-liadur (accessed on 10 November 2020).

87. RIEDER. Available online: http:/ / www.rieder.cz/produkty/protihlukove-steny-faseton/faseton-absorber.php (accessed on 10 November 2020).

88. Sgarbossa, A.; Boschiero, M.; Pierobon, F.; Cavalli, R.; Zanetti, M. Comparative Life Cycle Assessment of Bioenergy Production from Different Wood Pellet Supply Chains. Forests 2020, 11, 1127. [CrossRef]

89. Grubeša, S.; Suhanek, M.; Đurek, I.; Petošić, A. Combined acoustical and economical noise barrier optimization using genetic algorithms. Gradevinar 2019, 71, 177-185. [CrossRef]

90. Öztürk, T.; Öztürk, Z.; Çalis, M. A Case Study on Acoustic Performance and Construction Costs of Noise Barriers. Sci. Res. Essays 2012, 7, 4213-4229. [CrossRef] 